\title{
What Drives the Rapid Economic Growth in Azerbaijan? - An Application of the Solow Model
}

\author{
Shaokai Huang, Master Candidate \\ SHU-UTS SILC Business School, Shanghai University
}

doi: 10.19044/esj.2016.v12n22p380 URL:http://dx.doi.org/10.19044/esj.2016.v12n22p380

\begin{abstract}
Azerbaijan has undergone significant economic transformation and development since the country's independence in 1991. Azerbaijan has quickly transformed itself into an upper middle income country. The rapid economic development is mainly attributed to the exploitation of hydrocarbon resources (through production sharing agreements with foreign oil companies and foreign direct investment). Substantial reforms intended to support a market-based economy have been instrumental in facilitating economic growth. This paper applies the Slow Model to explain factors that drive the rapid economic growth in Azerbaijan. This paper discusses the theoretical role of capital, labor, and technology in economic growth and illustrates the impact of corresponding factors in practice, i.e., foreign investment, labor force, education, and technology, on Azerbaijan's economic growth.
\end{abstract}

Keywords: Economic Growth, Azerbaijan, Slow Model, Oil

\section{Introduction}

Nowadays, there is a great diversity of economic growth rates among countries. The economy of Euro zone countries are growing slowly, while emerging economies are experiencing rapid economic growth. Among emerging economies, Azerbaijan stands out as a case in point. Azerbaijan's GDP growth rate reached 26.4\% in 2005 (second highest GDP growth in the world in 2005 only to Equatorial Guinea), and in 2006 it exceeded 34.6\% (world highest). Azerbaijan's GDP grew 41.7\% in the first quarter of 2007, possibly the highest of any nation worldwide (RBC News, 2010). Despite the fact that in 2008 GDP growth rate dropped to $10.8 \%$, and dropped further to 9.3\% in 2009 (today.az, 2015), Azerbaijan has achieved significant economic growth which enabled it to complete its post-Soviet transition into a major oil based economy. A large amount of research pertains to what drives the economic miracle of Azerbaijan. This paper reviews a number of 
important determinants of economic growth. In particular, this paper applies the Slow Model to explain the rapid economic growth in Azerbaijan.

The remaining part of this paper is organized as follows. Section 2 discusses the role played by capital and labor in economic development, and introduces the development in Azerbaijan's capital market and labor market. Section 3 is devoted to the importance of productivity in economic growth and how Azerbaijan endeavors to improves its productivity through reform in education. Section 4 illustrates how saving rate influences economic growth. Section 5 reviews Azerbaijan's technology development based on the Slow Model. Section 6 concludes the paper.

\section{Capital and Labor}

Production mainly consists of capital stock and labor. A rise in capital investment would lead to a direct increase in GDP. Intuitively, if more capital stock was invested, then more output would be produced. More investment would also provide workers with more machinery / equipment to work with. Besides, new capital investment enables workers to make full and efficient use of new capital inputs, and therefore acquire a higher level of productivity. Hence, increasing capital stock tends to facilitate technological improvements, which eventually translate into increasing production. Like capital, labor force is also an essential factor of production. Increase in labor force, i.e., hiring more labor / having workers working longer hours, would lead to a higher output of goods and services in the same way as increase in capital stock. This paper does not consider changes in GDP that an economy experiences due to fluctuations in aggregate demand during the business cycle. This paper discusses long-run economic growth. Therefore, it is the expansion of an economy's productive capacity that is considered, which is shown graphically by an expansion in the production possibilities frontier. Therefore, increase in capital / labor or both leads to increase in in potential output, i.e., the production possibility frontier shifts outward.

Increase in capital played a major role in Azerbaijan's economic growth. As of October 2014, Azerbaijan holds the highest foreign investment per capita among the Commonwealth of Independent States (CIS) countries. Germany, for example, has invested approximately \$760 million into the Azerbaijani economy, and approximately 177 German companies operate within Azerbaijan. Since gaining its independence, companies have invested $\$ 174$ billion into Azerbaijan. Foreign investment accounts for around half of that amount (Jafarova, 2014).

Massive reform in Azerbaijan's labor market has lead to significant increase in Azerbaijan's labor force. One of the main trends of the social policy realized in Azerbaijan during last years is the formation of the country population's employment policy and advantageous use of labor force. The 
realization of reforms in economy, especially privatization of enterprises and organizations in the state property were the reasons of significant changes in distribution of employment by state and non-state sectors. One of the main aspects of employment and unemployment problems solution of population in the country is connected with realization of strategy of foreign investments' involvement in the country economy. In connection with that definition of role of foreign capital directed to Azerbaijan economy is one of the important duties in solution of employment and unemployment problems of the country population. In 2014, the number of persons employed in joint enterprises and enterprises with foreign investment functioning in the country being increased approximately for 2.8 times reached from 35.1 thousand people to 97.6 thousand compared to 2000. In 2014, 2.35 million or $51.1 \%$ of the total number of employed population in economy were engaged in production fields (agriculture, fishing, industry and construction) and number of people employed in the field of service was 2.2529 million and that made $48.9 \%$ of employed population (The State Statistical Committee of the Republic of Azerbaijan, 2015).

\section{Productivity}

Numerous empirical examples reveal that it is the growth of productivity that drives economic growth in the long run. Better productivity tends to make markets more competitive and boost the economy. More investment in human capital, e.g., improvement in education and increased spending on worker training, is considered essential to improve production efficiency. Since developing countries are not fully utilizing existing natural resources and labor force, upgrading workers' skills would lead to a larger portion of economic growth. Besides, diffusion of knowledge and income differences can arise because some countries are not yet employing the best available technologies (Romer: 1996). This enables developing countries to adopt modern technologies from developed countries without reinventing the wheels and thus benefit from technological progress. Figure 1 shows how productivity influences total factor productivity. As can be seen in the diagram, if productivity increases, with the same quantity of capital K0, real GDP increases from Y0 to Y1. 


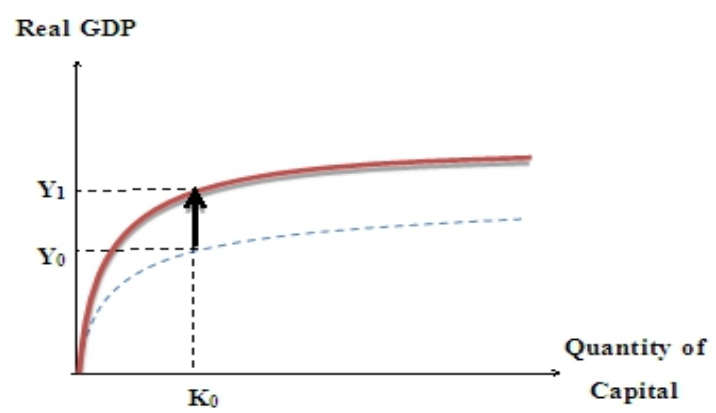

Figure 1 Total Factor Productivity

Realizing the importance of education and its positive impact on productivity, Azerbaijan has attached great importance to education. Since independence, one of the first laws that Azerbaijan's Parliament passed was to adopt a modified-Latin alphabet to replace Cyrillic. Other than that the Azerbaijani system has undergone little structural change. Initial alterations have included the reestablishment of religious education (banned during the Soviet period) and curriculum changes that have reemphasized the use of the Azerbaijani language and have eliminated ideological content. In addition to elementary schools, the education institutions include thousands of preschools, general secondary schools, and vocational schools, including specialized secondary schools and technical schools. There are 36 state-run and 15 private universities in Azerbaijan (Ministry of Education, 2011). Because Azerbaijani culture has always included great respect for secular learning, the country traditionally has been an education center for the Muslim peoples of the former Soviet Union. For that reason and because of the role of the oil industry in Azerbaijan's economy, a relatively high percentage of Azerbaijanis have obtained some form of higher education, most notably in scientific and technical subjects. Several vocational institutes train technicians for the oil industry and other primary industries.

The Slow Model assumes that the production function is $Y=A F(K, L)$, in which $\mathrm{Y}$ is output, $\mathrm{A}$ is technology, $\mathrm{K}$ is capital, and $\mathrm{L}$ is labor. At the very early stage of the setting up of the model, it is assumed that population / labor remain constant. Output changes due to variations in the capital input. Figure 2 shows the relation between output and changes in capital stock. 


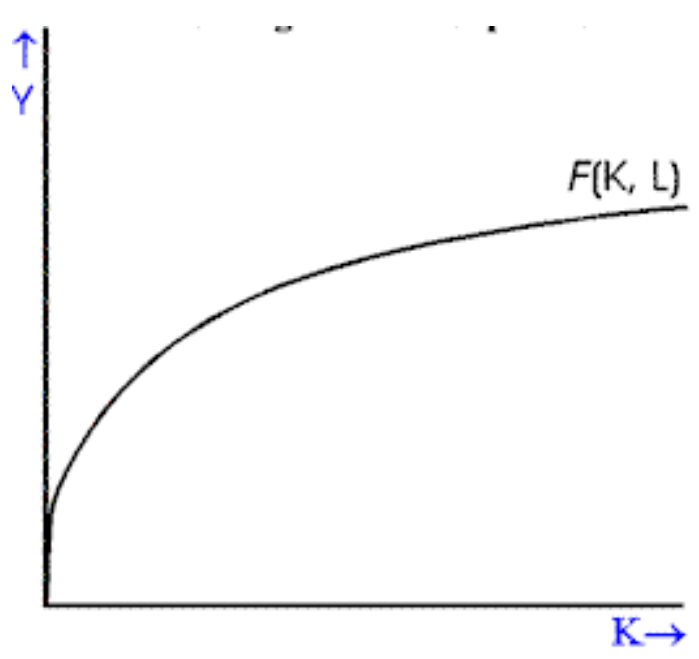

Figure 2 The Relation between Output and Changes in Capital Stock

The slope of the curve at any point represents the marginal product of capital. As can be seen in the diagram, the slope in the graph decreases because of the diminishing marginal productivity of capital. This implies that as an additional unit of capital is added to a fixed labor supply, the increase in output is positive but less than the extra output generated from the addition of the previous unit of capital.

The slowing down of economic growth of Azerbaijan provides empirical evidence to support the theory of diminishing marginal output. Azerbaijan's fast growth rate did not sustain. The real GDP growth rate for 2011 was expected at $3.7 \%$ but had dropped to $1 \%$. A developing country like Azerbaijan can have an economic growth rate as high as $25 \%$ in the initial economic boom, whereas in developed countries such as Germany, United Kingdom, France, the growth rate remained fairly stable historically. This stagnant growth rate are mainly due to maximum utilization of existing natural resources, labor, capital and land. Consequently, the growth rate became stable because of limited potential economic capacity. The same pattern of growth rate is observed in the economic growth of Azerbaijan over the past few years. When a huge amount of oil was first discovered and exploited, the economy of Azerbaijan took a dramatic leap. As production further increases and approximates its maximum, the growth rate slows down.

\section{Saving Rate}

The Slow Model assumes a depreciation rate $\delta$, and a saving rate s. Figure 3 shows the changes in the capital stock. To the left of $\mathrm{K}^{*}$, total savings exceeds the amount of savings required to replace depreciated capital 
stock and the capital stock increases (move to the right along the horizontal axis toward $\mathrm{K}^{*}$ ). To the right of $\mathrm{K}^{*}$, total savings is inadequate to replace depreciated capital stock and the capital stock falls (move to the left along the horizontal axis toward $\mathrm{K}^{*}$ ). At $\mathrm{K}^{*}$, the capital stock remains constant as the value of total savings equals the value of depreciated capital that needs replacement.

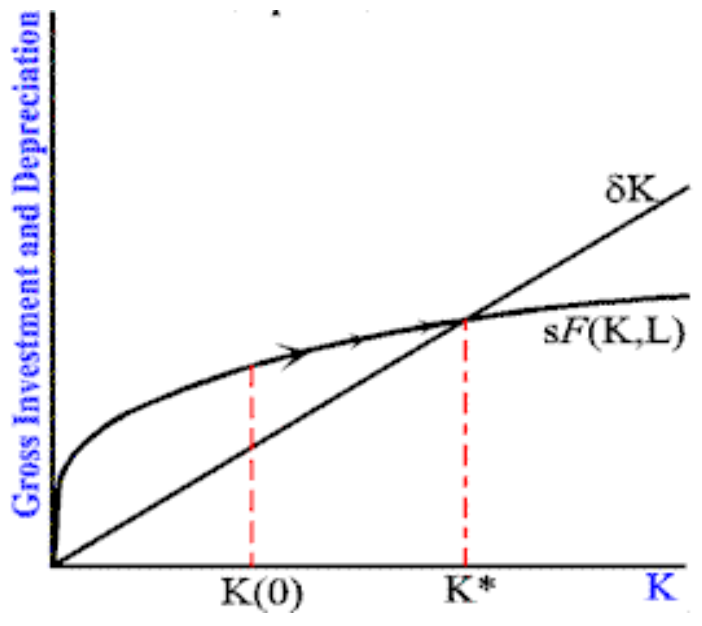

Figure 3 Changes in the Capital Stock

Figure 3 clearly reveals that savings rates sufficient to keep the net capital stock positive are required for economic growth. Increasing the capital stock would make the economy expand. The net addition to capital is represented by a rightward movement to $\mathrm{K}^{*}$. As long as total savings are larger than depreciated capital, the economy continues to add to its capital stock and move towards $\mathrm{K}^{*}$. At $\mathrm{K}^{*}$, net investment is zero and all savings go towards the replacement of depreciated capital This point is called "The Steady State”. At the steady state, net investment equals zero and the capital stock remains constant at $\mathrm{K}^{*}$.

The Slow Model indicates that if national saving rate rises, growth will temporarily rise above its long-run rate as the economy shifts to its new equilibrium. However, long-run equilibrium growth is independent of the saving rate or the population growth rate. If all countries have access to the same technology, all should have the same steady-state (long-run) growth rate. If a country raises its investment rate, it will experience a period of higher-than-normal growth as the economy adjusts to its new, higher growth path. Nevertheless, once the adjustment has occurred, growth will revert to the steady-state level (Sloan: 2000). Figure 4 shows how output increases with increase in the saving rate. As can been seen, a higher saving rate leads to an expansion of output, which is graphically represented by an upward shift of the production curve. 


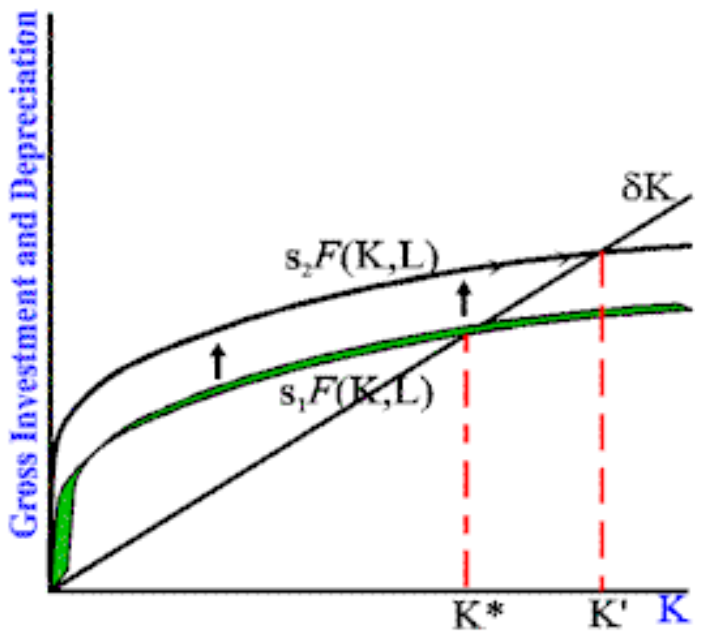

Figure 4 Increase in the Saving Rate

By 1 April 2010, 47 banks, 631 bank branches function in Azerbaijan. One of banks was founded with participation of state capital, 23 of foreign capital. To the same date, 98 non-bank credit organizations operate in the republic along with banks. Growth of real money incomes of population, development of trust in bank system, improving the legal bases of protection of interests of creditors and depositors, in particular launch of "Deposits Insurance Fund" were the criteria characterizing rapid growth of deposits of population. As of 1 April 2010, bank deposits of population were equal to 2,4 billion AZN. 33.3\% of them were long-term deposits (higher than a year). As of 1 April 2010, bank credits to customers is 8.5 billion AZN, which makes 70.5\% of bank assets (Heydar Aliyev Foundation, 2007).

\section{Technology}

Moreover, the Slow Model indicates that technological advancements do boost the economy until the economy becomes stagnant (Sloan: 2000). In addition, one of the key reasons for economic stagnancy is "diminishing returns to physical capital" (Krugman: 2008). Differences in the rate of technological change among countries explain much of the variation in growth rates. The Slow Model argues that the rate of return on capital is lower in countries with more capital per worker. Thus, capital tends to flow from rich countries to poor countries. This process takes place when the amount of human capital per worker and the state of technology are held fixed. Therefore, increase in the quantity of physical capital per worker leads to a less than proportionate increase in productivity. To experience further economic growth, essential investments are required to adopt advanced technologies, innovative manufacturing processes, skilled labor etc.. Principally, The Slow Model enlightens that countries will eventually 
converge to balanced growth path, i.e., poor countries are expected to catch up with rich countries.

In the 21st century, a new oil and gas boom helped to improve the situation in Azerbaijan's science and technology sectors, and the government launched a campaign aimed at modernization and innovation. The government estimates that profits from the information technology and communication industry will grow and become comparable with those from oil production. Azerbaijan has a large and steadily growing Internet sector, mostly uninfluenced by the global financial crisis; rapid growth is forecast for at least five more years (Euronews, 2010). The country has also been making progress in developing its telecommute sector.

\section{Conclusion}

In conclusion, the main drivers of Azerbaijan's fast economic growth rates mainly lie in population, capital, saving rate, and technology. Most of the developed countries have already experienced and developed a strong economic regime through industrialization. Whereas a developing country, for example Azerbaijan, has recently started to experience technology revolution and therefore gained larger economic welfare. The abundance of raw materials, rapidly growing population, and adoption of innovations provide the basis for an economic boom. Nevertheless, as Azerbaijan benefits from technology revolution and enjoys faster economic growth, convergence will eventually occur when economic stagnancy arises. The principal reason why Azerbaijan grows at a faster pace is due to diminishing marginal productivity of capital. If Azerbaijan explores its economic capacity and approximates the maximum, its growth rate will also slow down as all developed countries have experienced.

\section{References:}

“Azerbaijan Aims for Hi-Tech State”. Euronews. Retrieved 19 December 2010.

“Azerbaijan - General Information”. Heydar Aliyev Foundation. Retrieved 22 May 2007.

“GDP Growth Makes 3.4\% in Azerbaijan in 2009”. today.az. Retrieved 3 March 2015.

Gregory, P., and Stuart R., Comparative Economic Systems, Fourth Edition, pp. 30-35, 1992, Houghton Mifflin Company.

Jafarova, Aynur. "Azerbaijan Leading Country in CIS for Foreign Investment Per Capita”, 2014, AzerNews. Retrieved 1 October 2014.

Krugman, P., Wells, R, and Graddy, K., Economics, European Edition, pp. 618-628, 2008, Worth Publishers, New York.

"Report on Works in Secondary and Higher Education Sector in 2009” (in 
Azeri). Ministry of Education, Republic of Azerbaijan, Retrieved 4 November, 2011.

"Ros Business Consulting - News Online”. Rbcnews.com. Retrieved 26 March 2010.

Sloan, J., Sloan, A., and Sutcliffe, M., Economics, Fifth Edition, pp. 614642, 2000, Pearson Education Limited.

The State Statistical Committee of the Republic of Azerbaijan, www.stat.gov.az/source/labour/indexen.php, Retrieved 31 August 2015. 